\title{
Organizational, Technological and Economic Indicators of Beef Cattle Production on Family Farms
}

\author{
Dragić ŽIVKOVIĆ ${ }^{1}$, Zoran RAJIĆ ${ }^{1}$, Sreten JELIĆ ${ }^{1}$,Zoran MILOVANČEVIĆ ${ }^{1}$,Bojan DIMITRIJEVIĆ ${ }^{1 *}$ \\ ${ }^{1}$ Department of Agricultural Economics. University of Belgrade, Republic of Serbia. \\ *)corresponding author, e-mail: bojandi@agrif.bg.ac.rs
}

BulletinUASVM Horticulture 72(2) / 2015

Print ISSN 1843-5254, Electronic ISSN 1843-5394

DOI:10.15835/buasvmcn-hort:10735

\begin{abstract}
The paper discusses the organizational, technological and economic aspects of the most important indicators of beef cattle production on family farms. Emphasis is placed on explaining the connections and relationships between organizational, economic, technical and technological business segments of family farm. The ultimate goal of this paper is to evaluate the strengths of the business, as well as the ways to eliminate or reduce the impact of those factors whose influence adversely affects the business. The data for this paper were collected from family farm business reports, throughout direct communication with employees, from relevant literature and internet. Several methods were applied, including: a method for content analysis, calculative and balance methods, spreadsheets, as well as method of comparative analysis and principles of business economics. Key success indicators of beef cattle production on the family farm suggest that, considering both observed years, the business achieved satisfactory results. Although there was a decline in productivity, total efficiency measured by the ratio of total income and total expenditure is on an uptrend. An investment turnover ratio show that 100 RSD invested in the production achieves 63 RSD of final product value in 2011, or 55 RSD in 2012. In both years, current assets covered the current liabilities. The family farm was not solvent in either of the observed years, except that in 2012 the solvency increased by $42 \%$ compared to the previous year, 2011 . Total debt increased by $45 \%$, whereas total operating assets increased by $106 \%$. Based on the obtained results it can be concluded that the observed family farm provides a good example of how organized and proper process technologies of cattle production may improve the achieved business results.
\end{abstract}

Keywords: cattle production technology, economic principles, family farm

\section{INTRODUCTION}

In the Republic of Serbia, as everywhere in the world, beef cattle breeding is the main category of cattle breeding, focused on intensive meat production. Countries with developed economy enhance beef production by guiding of genetic improvement of cattle features, selection within the race and expert consultation for improvement of the beef cattle base and cattle feeding. Scientific research and professional work realize proven solutions for applied production system and required meat quality.

Last few years the beef cattle production has not been competitive with the milk production. Consequently, the production of beef was significantly reduced and the producers have been trying to achieve bigger profit by better organization of work and savings in the production.

Serbia has favorable natural conditions for the development of livestock, but in the last 30 years a decreasing trend in number of cattle and calf heifers was recorded. Livestock production in Serbia is facing with obstacles, which are mainly results of insufficient attention (on all levels) paid to this agricultural sector (Bogdanov and Petronijević, 2009; Subić et al., 2009; Tomić et al., 2011).

Cattle breeding is the most important livestock sector in Serbia. According to the Report (P012) of the Statistical Office of Serbia, on 1/12/2013 balance, total number of cattle was 912,147. According to the 2012 Agricultural Census, total 
number of cattle in the Republic of Serbia on the family farms had a share of $91.7 \%$.

Based on Veterinary Department data in 2012 it was registered 1,414 holdings for cattle fattening, from which 80 farms are of 500 heads capacities. Middle sized farms breed 100-499 heads and their number is 204 in Serbia. There are also1130 other (unidentified) capacities for fattening.

In the cattle meat production in Serbia, Simmental breed is dominant. "In the last several decades in non-European and some European countries Simmental breed is being raised exclusively for the purposes of specialised meat production by breeding in pure breed or by crossing with other breeds" (Perišić et a.l, 2014).

In total livestock production in Serbia, a cattle breeding is on the first place, which with the milk and meat production in 2012 shared about 43\% of total value of livestock production. Quantities of beef and veal meat in Serbian market are not sufficient to cover domestic consumption. Beef meat export quota (under preferential status) for EU market is 8,880 tons/year, but only about $5 \%$ is used. There are potentials for beef and veal meat export on the Russian Federation market and Asian countries as well. There is a small increasing of number of cattle on slaughter line $(5 \%)$ in relation to total number of slaughtered animals for period 2011 - 2013. On the other hand, in the beef meat production there is recorded decreasing in the number of breeding animals, which leads to smaller number of fattening cows as well. Therefore, it is necessary to establish specialized systems aimed for beef meat production (Stevanović and Budimirović, 2014).

The family farm has undergone major changes which were caused by a series of economic, political and social factors. The biggest changes have occurred in recent years as a direct result of the economic crisis. However, the circumstances indicate that, even today, the current belief is that more significant changes in improving of cattle production may be achieved only by greater involvement of the state and other factors that would encourage farmers to develop and promote the production on their own farms (Romčević et al., 2007).

\section{MATERIALS AND METHODS}

During the work, organizational-economic and technical-technological conditions and results of business of the family farm for cattle production were considered. The analysis of cattle fattening was carried out (in organizational and technological sense), as well as the movement of turnover, production costs, financial results and economic business principles of the family farm.

Data for this paper were collected from internal documentation of family farm i.e. business reports, from relevant institutions (Statistical Office of Serbia, Veterinary Department), from literature and internet by using content analysis method, but also throughout direct communication with family farm employees - interview method. In determining business results calculative and balance methods were applied, as well as spreadsheets, method of comparative analysis and business economics. The method of calculation of cattle fattening from calves to bulls was used in order to determin costs and economic results of obtaining goods and services and economic expediency of various business measures.

\section{RESULTS AND DISCUSSION}

The family farm disposes of a farm with the capacity of 1.000 of beef cattle. Currently there are 500 steers and 50 head of heifers in the beef cattle production of Simmental breed, weighing 300 to $600 \mathrm{~kg}$. The facility in which animals are situated covers total area of $2048 \mathrm{~m}^{2}$ (length of $64 \mathrm{~m}$ and width of $32 \mathrm{~m}$ ). The space is arranged so that it contains four rows of boxes, a partition wall with the height of $1,7 \mathrm{~m}$, which divides the object in half and makes two units on the floor, two rows of boxes between which there is a cattle feed passage of $2.2 \mathrm{~m}$ width with cribs of $0.7 \mathrm{~m}$ width for each row. The total number of boxes in the facility is 40 , so that each row consists of 10 boxes, with length of $6 \mathrm{~m}$, width of $5.3 \mathrm{~m}$ (total box size is $31.8 \mathrm{~m}^{2}$ ). Objects are filled successively and 14 beef cattle are placed in each box.

Silage boxes are $20 \mathrm{~m}$ away from the facility for kettle accommodation. There are 5 trench silos with joint interior walls that are made of reinforced concrete, with length of $20 \mathrm{~m}$, width of $7 \mathrm{~m}$ and height of $1.8 \mathrm{~m}$, with a capacity of $250 \mathrm{of} \mathrm{m}^{3}$.

Economic effects for the production of silage may be viewed in the table 1 .

Feeding of beef cattle involves the preparation of meals in the mix trailer which affects better preparation, reduces labor costs, reduces loss of nutrients, better mixing is achieved, as well as better uniformity of all factions of food. Capacity of the mix trailers is $6 \mathrm{~m}^{3}$ and it fits $2500 \mathrm{~kg}$ of a ready meal. 
Tab. 1 Price of the silage cost

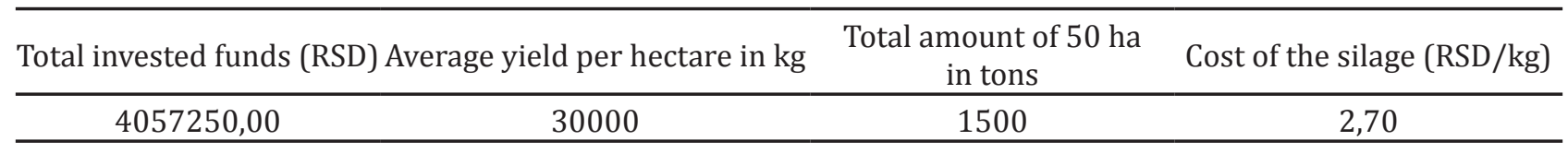

Corn silage is produced on the family farm, whereas a part is purchased during the preparation season. In addition, the composition of a meal includes the complete mixture for fattening of beef kettle T1, which should enable high growth and fast fattening. Meal is distributed twice a day.

In comparison with the milk production, beef cattle fattening is characterized by more modest requirements regarding accommodation conditions, live labor, health care of livestock and other zoo-technical measures, although within this line significant differences may occur in this regard, depending on the age of beef cattle (Krstić and Lučić, 2000). However, apart from that, in order to ensure the production of high quality meat, it is necessary to carefully evaluate the entire production cycle and apply the principles of modern technology of nutrition and breeding, which implies strictly balanced meals for certain production phases. Animal feed should contain all necessary elements for normal health, reproduction and maximum production results. Factors affecting the success of beef cattle are: race, age, sex, composition of meals, feeding manner, water supply, method of holding.

The farm deals with the intensive fattening of beef cattle with initial weight from 290 to 310 $\mathrm{kg}$, whereas the final weighing is from 550 to 600 $\mathrm{kg}$. Characteristics of such fattening are reflected in the fact that high-quality feed and good care provide high daily growth, ranging from 1.100 to $1.300 \mathrm{~g} /$ day. Age of the beef cattle at the beginning of fattening is from 6 to 7 months, whereas the final weight is achieved at 12 to 15 months of age.

Male beef cattle are used for fattening, with larger growth, quality meat and more favorable feed conversion, whereas a smaller proportion consists of female beef cattle that are not allowed for breeding. Due to a change in the composition of growth which occurs over time (proportion of dry matter increases and the presence of water in the growth reduces), the tendency is that fattening is completed as soon as possible, and thereby achieve the appropriate body weight.
During the process of beef cattle fattening, several important elements can be detected, which should be the subject of observation and analysis. For example, the most important criteria when constructing the model of farms focused on cattle breeding Krstić and associates took into account are the following: the intensity of production, size of land holding, type of cattle production, cattle fattening technology, type of meal and the manner of livestock keeping (Krstić et al., 2003). Beef cattle nutrition makes the basis of fattening technology, so that its impact on results and costeffectiveness of the fattening is the greatest. Feed makes 70 to $80 \%$ out of the total costs. The goal of the production is that the fattening lasts as short as possible so that maximum of daily gain may be achieved with minimum feed consumption.

Manner of feeding can not be considered separately from other factors, since all of them affect the choice of a particular type of food, and thus the success of the fattening. Each type of feed represents the intensity of fattening, or possible size of the daily gain and the length of fattening, depending on body weight and condition of beef cattle when placing the animals in breeding and at the end of it. Different intensity of beef cattle production may be achieved with the same type of feed, whereas types of feed may be changing with each other by using different intensities. At the beef cattle production farm organized like this, animals are being fed intensively all the time, whereas they make maximum use of their genetic potential.

Modern management of family farm can not be imagined without data of costs and economic results of obtaining goods and services and economic expediency of various business measures (Gogić, 2009). Therefore, the method of calculation was used in making of this paper (Table 2).

The physical volume of production is decreased by $24 \%$ in comparison to 2011 . Costs of material are also reduced in comparison to 2011 but, due to the decrease of physical volume in production volume, they increased by $4 \%$ per 
Tab. 2 Calculation of cattle fattening from calves to bulls (140-550 kg)

\begin{tabular}{|c|c|c|}
\hline & I phase of fattening (from 140 to $300 \mathrm{~kg}$ ) & RSD \\
\hline 1. & Calf $140 \mathrm{~kg} \times 430,00 \mathrm{RSD}$ & $60.200,00$ \\
\hline 2. & Feed - concentrate $(300 \mathrm{~kg}-140 \mathrm{~kg}=160 \mathrm{~kg} \times 5,5 \mathrm{~kg} \times 18,00 \mathrm{RSD})$ & $15.840,00$ \\
\hline \multirow[t]{2}{*}{3.} & Transport costs & $1.000,00$ \\
\hline & II phase of fattening (from 300 to $550 \mathrm{~kg}$ ) & \\
\hline \multirow[t]{2}{*}{1.} & Feed - concentrate $(550 \mathrm{~kg}-300 \mathrm{~kg}=250 \mathrm{~kg} \times 7,8 \mathrm{~kg} \times 18,00 \mathrm{RSD})$ & $35.100,00$ \\
\hline & I phase of fattening + II phase of fattening $=$ & $112.140,00$ \\
\hline 1. & $\begin{array}{c}\text { Medical treatment, the risk of death and emergency slaughter in } \\
\text { I and II phase of fattening (5\%) }\end{array}$ & $5.607,00$ \\
\hline 2. & The accompanying veterinary documents & 500,00 \\
\hline \multirow[t]{6}{*}{3.} & Organization and fattening service $(550 \mathrm{~kg}-140 \mathrm{~kg}=410 \mathrm{~kg} \times 9,00 \mathrm{RSD})$ & $3.600,00$ \\
\hline & Total 1 bull $(550 \mathrm{~kg})$ & $121.847,00$ \\
\hline & Market price of $1 \mathrm{~kg}$ of live bull: $251,00 \mathrm{RSD}$ & \\
\hline & Cost of $1 \mathrm{~kg}$ of live bull: $221,70 \mathrm{RSD}$ & \\
\hline & Difference in price: $29,30 \mathrm{RSD} / 114,00 \mathrm{RSD}=0,26 €$ & \\
\hline & Profit per one bull: $550 \mathrm{~kg} \times 0,26 €=143 €$ & \\
\hline
\end{tabular}

Tab. 3 Indicators of business success

\begin{tabular}{lcccc}
\hline & & \multicolumn{2}{c}{ Year } & \multicolumn{2}{c}{ Index } \\
& & 2011 & 2012 & $2012 / 11$ \\
\cline { 3 - 5 } & Gross profit/average number of employees & 1.641 & 932 & 57 \\
\hline 2 & Net profit/ average number of employees & 1.641 & 932 & 57 \\
\hline 3 & Total income x 100/total expenditure & 102,25 & 103,65 & 101 \\
\hline 4 & Operating income x 100 RSD/operating expense & 102,49 & 106,14 & 101 \\
\hline 5 & Total income/total engaged assets & 0,63 & 0,55 & 87 \\
\hline 6 & Net profit x 100/ total engaged assets & 0,79 & 2,75 & 348 \\
\hline 7 & Liquidity ratio & 1,17 & 1,25 & 107 \\
\hline 8 & Solvency & 0,48 & 0,67 & 142 \\
\hline
\end{tabular}

unit of a product. Regardless of the debt of the family farm or negative financial result of financial business operations, the total gross financial result is positive in both years. Furthermore, in 2011 it makes total of 16.407.000 RSD and it is increased compared to 2012, when it was 10.257.000 RSD.

The largest decreaseis recorded in productivity (index 57). The total cost measured by the ratio of total income and total expenditure shows an uptrend since the 100 RSD of expenditure makes 2.25 RSD of surplus income in 2011, or 3.65 RSD of surplus income in 2012 (Table 3). 100 RSD of expenditure in 2009 makes 2.49 RSD of operating income, or 6.14 RSD in 2010 (the ratio of operating income and operating expense).
An investment turnover ratio shows that each 100 RSD invested in the production achieves 63 RSD in 2011, or 55 RSD in 2012 of final product value. Reverse process determines the speed of turnover of engaged assets, or the time period in which the invested funds may be achieved through cash incomes from realization of obtained products. In both years, current assets covered the current liabilities. The family farm was not solvent in either of the observed years, except that in 2012 the solvency increased by 42\%. In 2011 total operating assets increased by $106 \%$ and total debts increased by $45 \%$. 


\section{CONCLUSION}

Serbia has favorable natural conditions for the development of livestock but insufficient attention was paid to this agricultural sector and in the last 30 years a decreasing trend in number of cattle and calf heifers was recorded. Still, cattle breeding is the most important livestock sector in Serbia. On 1/12/2013 balance, total number of cattle was 912,147 . Total number of cattle in the Republic of Serbia on the family farms had a share of $91.7 \%$. In 2012 there was 1,414 registered holdings for cattle fattening. In the cattle meat production in Serbia, Simmental breed is dominant. Quantities of beef and veal meat in Serbian market are not sufficient to cover domestic consumption. Besides, there are great, unused potentials for beef and veal meat export from Serbia on the markets of Russian Federation, Asian countries and EU. Therefore, it is necessary to establish specialized systems aimed for beef meat production as soon as possible. Otherwise, existing problems may be expected in the future.

The results of this case study could be extended to a different extent to other family farms with the similar type of production as well. It shows the way how to organize beef production under given circumstances, important parameters that should be traced as well as how to determin costs and economic results of obtaining goods and services and economic expediency of various business measures. Namely, the observed family farm provides a good example of how organized and proper process technologies of fattening may achieve good results. The overall agricultural production on the farm is focused on meeting the needs of livestock production. Comprehensively watching, the farm meets most of the zoo technical requirements, but every day tends to solve the problems and improve overall production. In the future period greater production of concentrated feed on the farm should be enabled and highquality hay should be introduced into meals, which will partially enable the achievement of better business results.

\section{REFERENCES}

1. Bogdanov N, Petronijević M (2009). Structural Changes of Agricultural Sector - experience after two years of transition. Chapter: Agriculture and Rural Areas of Serbia, DAES - Društvo agrarnih ekonomista Srbije, University of Belgrade Faculty of Agriculture, Belgrade, pages 1-24.

2. Gogić P (2009). The Theory of Costs with Calculations. Faculty of Agriculture, Belgrade, page 173.

3. Krstić B, Lučić Đ (2000). Organization and Economics of Production and Processing of Livestock Products. Faculty of Agriculture, Novi Sad.

4. Krstić B, Smiljić S (2003). Theory and Practice of Systematic Approach to the Business Management in Agriculture. Consecco Institute, Belgrade, page 91.

5. Munćan P, Živković D (2004). Management of Work and Production in Agriculture. Faculty of Agriculture, Belgrade.

6. Perišić P, Bogdanović V, Mekić C, Ružić-Muslić D (2014). Simmental breed production characteristics and breeding goals. International Symposium on Animal Science, University of Belgrade Faculty of Agriculture, Belgrade, Serbia, page 29.

7. Rajić Z (2003). Model for Optimization of the Production of Industrial Slaughterhouse, PhD Thesis, Faculty of Agriculture, Novi Sad.

8. Rodić J, Vukelić G (2003). Theory and Analysis of Balancing. Faculty of Agriculture, Belgrade.

9. Romčević L, Trifunović G, Lazarević Lj (2007). Cattle Breeding in Serbia. Monograph. Faculty of Agriculture, University of Belgrade, Belgrade.

10. Statistical Office of Serbia (2012). 2012 Agricultural Census

11. Stevanović J, Budimirović N (2014). Livestock farming in rural areas. International Symposium on Animal Science, University of Belgrade Faculty of Agriculture, Belgrade, Serbia, pages 496-499.

12. Subić J, Vasiljević Z, Ivanović S (2009). Education of agricultural producers intended to improve farm operations and management. $113^{\text {th }}$ Seminar of the European Association of Agricultural Economists: «The role of knowledge, innovation and human capital in multifunctional agriculture and territorial rural development», Belgrade, Serbia, pages 257-265.

13. Tomić D, Ševarlić M, Zekić S (2011). Agrarna i ruralna politika u Srbiji nužnost ubrzanja reformi. DAES - Društvo agrarnih ekonomista Srbije, Novi Sad, page 171. 